\begin{tabular}{l|c|c|}
\hline & International Journal of Current Research in \\
Biosciences and Plant Biology \\
EXCELLENT \\
PUBLISHERS
\end{tabular}

Original Research Article

doi: $\underline{\text { https://doi.org/10.20546/ijcrbp.2018.505.008 }}$

\title{
Selection and In-Vitro Potentials of Amylolytic Mold from Several Local Ragi Tapai in West Sumatra
}

\author{
Inelvi Yulia, Periadnadi and Nurmiati*
}

Biology Department, Faculty of Mathematics and Natural Sciences, Andalas University, Limau Manis, Sumatera Barat 25163, Indonesia

*Corresponding author.

\begin{tabular}{|c|c|}
\hline Article Info & ABSTRACT \\
\hline $\begin{array}{l}\text { Date of Acceptance: } \\
21 \text { April } 2018\end{array}$ & \multirow{4}{*}{$\begin{array}{l}\text { Ragi tapai is an inoculum for tapai fermentation in Indonesia, ragi tapai contains } \\
\text { several microbes and hydrolase enzymes. In West Sumatra ragi tapai preparations } \\
\text { varies by region because they cultivate themselves based on their own knowledge } \\
\text { traditional knowledge) so the results obtained in each region will vary. This study } \\
\text { aims to identify the most potent amylolytic mold in several samples of local ragi } \\
\text { tapai in West Sumatra (Padang, Padang Panjang, Pesisir Selatan, Payakumbuh, } \\
\text { Solok, Padang Pariaman, Batusangkar). For selection and characterization RFA, } \\
\text { PDA, MEA, Czapek Agar, CMCA and GPACaCO } 3 \text { were used as medium. The } \\
\text { results showed there were six potential amylolytic species of mold in ragi tapai } \\
\text { such as Aspergillus oryzae, Aspergillus terreus, Aspergillus fumigatus, Aspergillus } \\
\text { candidus, Aspergillus clavatus and Geotricum sp. Geotricum sp. showed the highest } \\
\text { amylolytic in-vitro potential. }\end{array}$} \\
\hline $\begin{array}{l}\text { Date of Publication: } \\
06 \text { May } 2018\end{array}$ & \\
\hline Keywords & \\
\hline $\begin{array}{l}\text { Amylolytic mold } \\
\text { Aspergillus species } \\
\text { Ragi Tapai } \\
\text { Selection }\end{array}$ & \\
\hline
\end{tabular}

\section{Introduction}

Ragi tapai is an inoculum for fermentation of carbohydrate materials such as cassava tapai. Microbes from ragi tapai produce hydrolase enzymes such as amylases. The existence of microbes in ragi tapai is influenced by materials and process. In general, ragi tapai is made using a mixture of rice flour and several types of spices. According to Handayani (2007) the addition of different of spices can affect the presence of microbes in ragi tapai. Microbes used in the process of tapai making can be mold, yeasts and bacteria. Periadnadi (2005) reported that the biochemical processes in cassava fermentation include several stages, but the important process is conversion of starch into sugar by amylolytic mold isolated from ragi tapai. Gandjar (2003) also reported that in ragi tapai there are various types of mold, yeast and bacteria. Mold in ragi tapai have strong amylolytic potensial to conversion of carbohydrates into sugars. The conversion process of starch into sugars was known as saccharification. Saccharification is a process of 
converting starch into sugars byhydrolase enzyme (Lima and Natalense, 2012).

Optimization of saccharification is a factor that can increase sugar production. The main materials for saccharification process are chemical compounds, commercial enzymes and microbes. However, chemical compounds and commercial enzymes is not effective for saccharification. According to Adini et al. (2015) the conversion method for enzymatic hydrolysis by Aspergillus niger can produce higher value of reducing sugar, compared with acid hydrolysis using $1 \% \mathrm{H}_{2} \mathrm{SO}_{4}$. So it is necessary to find another alternative such as of amylolytic mold that can convert starch into sugars and optimize the process of starch conversion. The amylolytic potential of ragi tapai microbe can be used in the process of starch hydrolysis without the needs of commercial amylolytic enzymes or other chemical compounds.

\section{Materials and methods}

The research was conducted using survey method with several stages including: isolation and characterization (morphology and in-vitro potency) of amylolytic mold from several West Sumatra local ragi tapai.

\section{Isolation amylolytic mold}

Isolates of amylolytic mold was isolated from several local ragi tapai. Isolate of amylolytic mold used as isolate is a mold that has the largest clear zone on Rice Flour Agar (APB) medium. The isolates were purified on Potato Dextrose Agar (PDA) medium.

\section{Characterization of amylolytic mold isolates}

\section{Macroscopic characters of mold isolates}

Isolates of amylolytic mold were cultured on Potato Dextrose Agar (PDA), Carboxy Methyl Cellulose Agar (MEA) and Czapek Agar medium. For identification, the identification book by Samson and Van Reenen-Hoekstra (1988) and Barnett and Hunter (1972) were used.

\section{Microscopic isolate}

Isolates of amylolytic mold were observed for conidia head, vesicles and phialides on a microscope. For identification, the identification book by Samson and Van Reenen-Hoekstra (1988) were used.

\section{In-vitro potential isolate}

For analyze In vitro Potency, medium APB, CMCA and Glucose Peptone Agar + Calcium Carbonate $\left(\mathrm{GPA}+\mathrm{CaCO}_{3}\right)$ were used. Potential in-vitro isolates was observed by counting the amylolytic, cellulolytic and fermentative index. Calculate index of the isolate with largest clear zone was obtained by calculating the ratio between the diameter of the clear zone with the diameter of the colony of mold (Jamilah et al., 2009).

\section{Results and discussion}

\section{Characteristics of amylolytic mold isolates}

The amylolytic mold found in this research were classified to Division of Amastigomycota, Class Deuteromycetes (Alexopoulos and Mims, 1979). Amylolytic mold were classified into genera Aspergillus and Geotrichum. According to Dwita (2009) in ragi tapai there are Aspergillus which has higher amylase activity than isolate Geotricum sp. and Mucor rasemosus. Fig. 1 shows the amylolytic mold on Rice Flour Agar medium. Description of each amylolytic mold as follows:

\section{Aspergillus oryzae}

Macroscopic observations showed that colony grew very quickly in MEA and Czapek Agar. At the beginning of incubation the colony is white and in the seventh day changed to be yellow-green with colony diameter 6-6.5 $\mathrm{cm}$. According to Oramahi (2006) Aspergillus oryzae colonies on medium Czapek Agar and MEA are yellow-green 
with $6 \mathrm{~cm}$ diameter. Microscopic observation showed the conidia head is radiate, subglobose or semicircular vesicles with phialides directly appearing on the vesicle or metulae. This is in accordance with the characteristics by Samson and van Reenen-Hoekstra (1988) that the conidia head radiate, vesicle subglobose, phialides often directly borne on the vesicle or on metulae and conidia ellipsoidal when young, globose to sub-globose when mature (Fig. 2).

\section{Aspergillus terreus}

Macroscopic observations showed that colony grew very quickly in MEA and Czapek Agar. At the beginning of incubation colony showed white coloration while on the seventh day of incubation colony coloration changed to be green-yellow with colony diameter $4-7 \mathrm{~cm}$. From microscopic observation it can be seen that this mold has a yellow conidiophore with type of conidia heads is columnar and compact and the phialides appear on top of the metulae with globose and ellipsoidal type of conidia. This is in accordance with Samson and van Reenen-Hoekstra (1988) that the colony of this mold has an yellow-brown conidiophores, becoming darker with age and diameter colony is 3.5-5 within seven days. Conidial heads compact, phialides borne on matule, vesicle subglobus and conidia globose to ellipsoideal (Fig. 3).

\section{Aspergillus fumigatus}

The macroscopic observation showed that the color of colony was green-yellow in MEA and Czapek Agar medium with colony diameter is about $5 \mathrm{~cm}$ on the seventh day incubation. Young colony showed white coloration but quickly change to green-yellow. According to Wangge (2012) young colony of A. fumigatus has the characteristics of white coloration that is rapidly changed to green with the formation of conidia. The conidiophore is short, and green (especially on the top). Vesicle is mace shaped and conidia shape ranges from globose to subglobose (Fig. 4).

\section{Aspergillus candidus}

The macroscopic observation showed that the color of colony was creamy white. The colony growth was slower on MEA and Czapek Agar medium. The colony diameter after 7 days incubation was $1.5-3 \mathrm{~cm}$. Conidiophore was arose from the agar or from mycelium area, color of conidia head was creamy white. Microscopically this mold has a form of conidia and globose and subglobose vesicle (Fig. 5). Phialides are sometimes borne directly on the vesicle but mostly on metulae (Samson and van ReenenHoekstra, 1988). The ability of Aspergillus to decompose amylum is due to the amylase enzyme content. Genus Aspergillus is the most dominant fungi group for starch decomposition process (Melliawati et al., 2006).

\section{Aspergillus clavatus}

Macroscopic observation showed the color of this colony was blue-green. Colony diameter was ranged from 2.5 to $3.5 \mathrm{~cm}$ after seventh days of incubation. This microscopic mold showed corresponding characteristics to A. clavatus in Samson's and van Reenen-Hoekstra identification book (1988) which are long conidiophores, conidial heads clavate that usually splitting into several divergent columns. Vesicle typically clavate, phialides borne directly on the vesicle and conidia ellipsoid (Fig. 6).

\section{Geotrichum sp.}

Macroscopic observation showed the color of this colony was white on MEA and Czapek Agar medium. This mold growth was slow and on the seventh day of incubation colony diameter was only $1 \mathrm{~cm}$. These characteristics correspond to the characteristic of Geotrichum sp. in Samson and van Reenen-Hoekstra's identification book (1988).

The characteristic of this colony is white mycelium and cylindrical, barrel-shaped or ellipsoidal conidia (Fig. 7). 


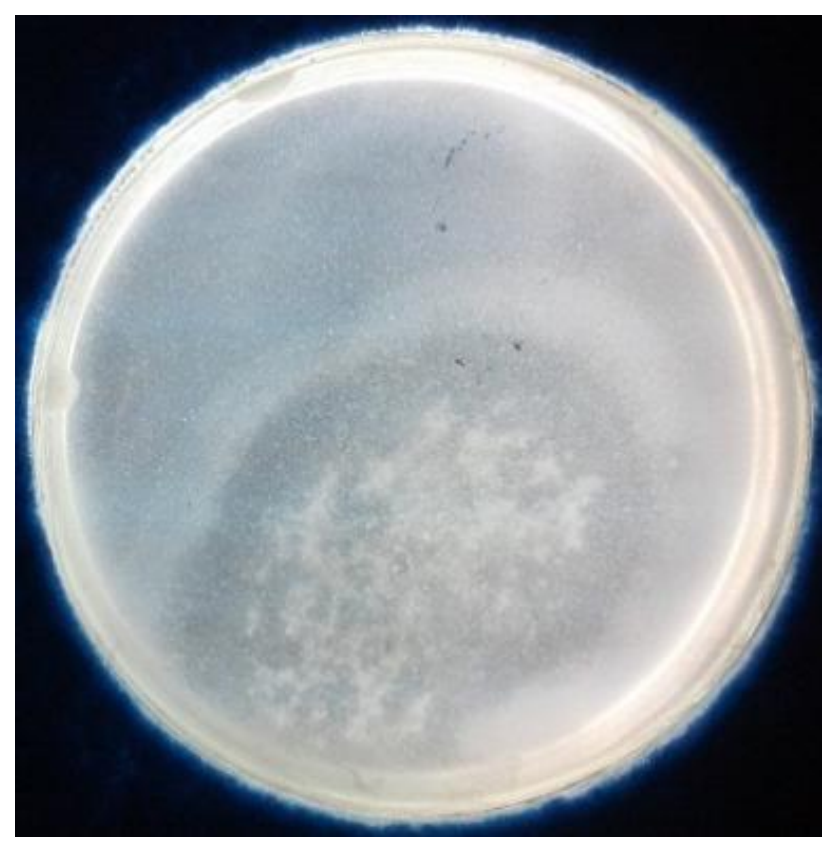

Fig. 1: Amylolytic mold on Rice Flour Agar (RFA) medium.

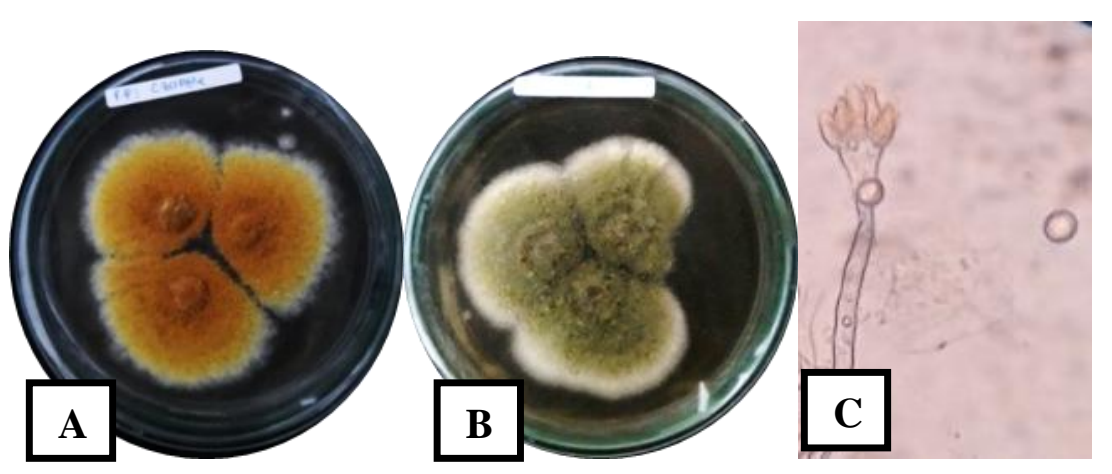

Fig. 2: Aspergillus oryzae. Colonies after 7 days incubation (A) Czapek Agar (B) MEA (C) A. oryzae at 40x magnification.

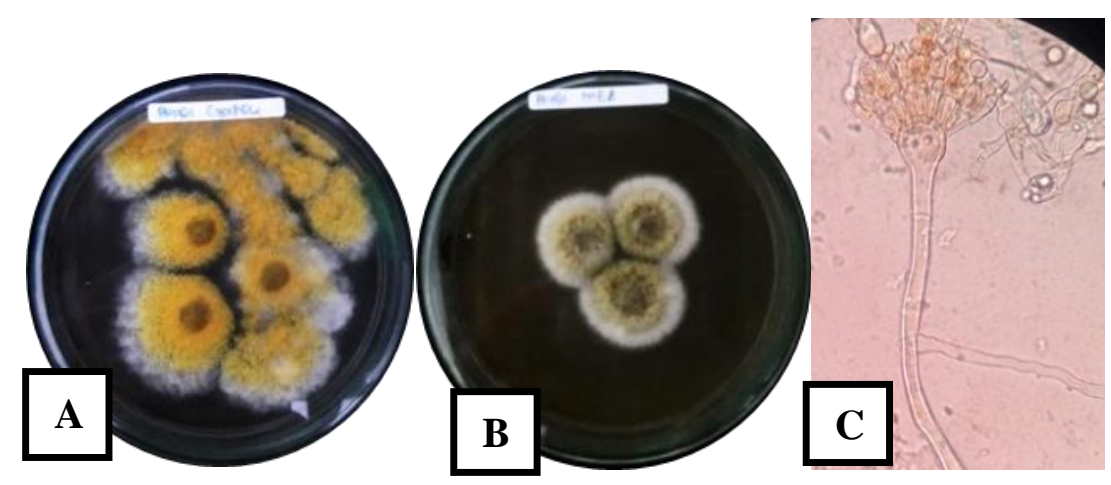

Fig. 3: Aspergillus terreus. Colonies after 7 days incubation (A) Czapek Agar (B) MEA (C) A. terreus at 40× magnification. 


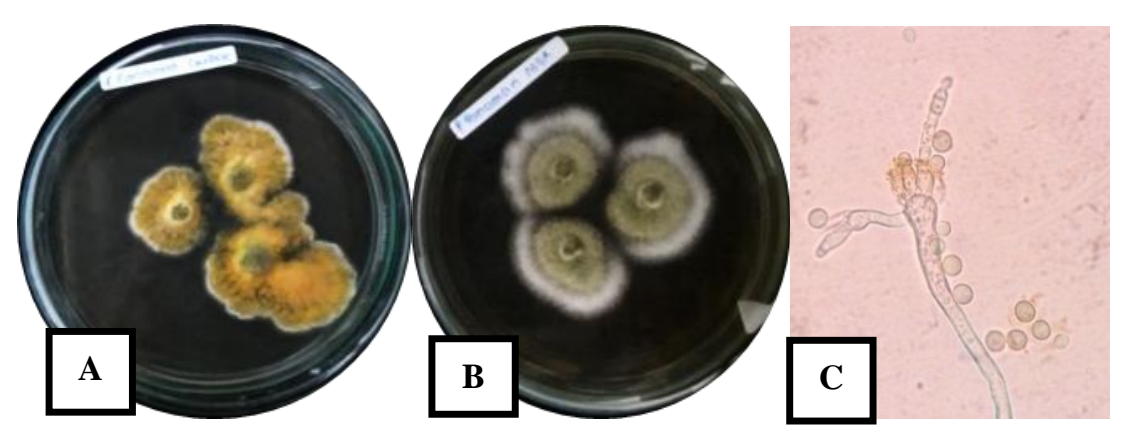

Fig. 4: Aspergillus fumigatus. Colonies after 7 days incubation (A) Czapek Agar (B) MEA (C) A. fumigatus at 40× magnification.
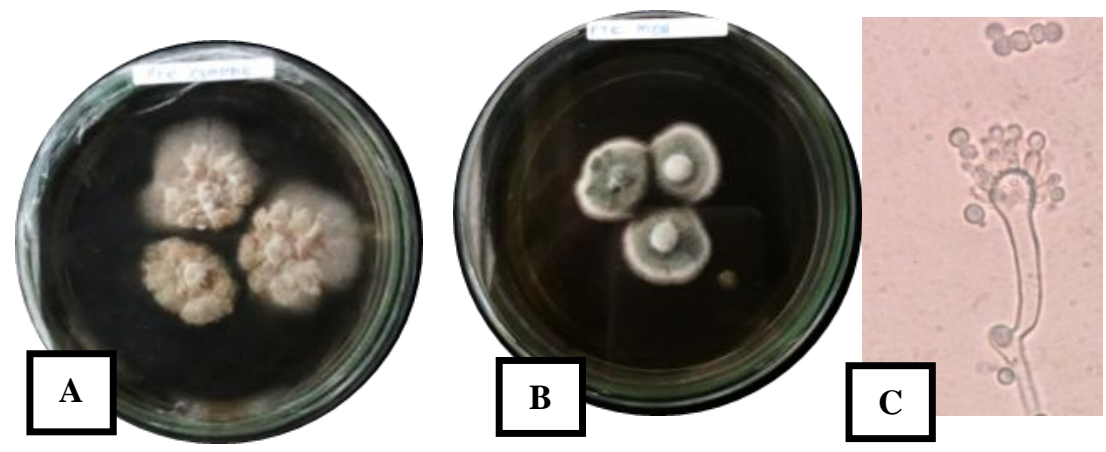

Fig. 5: Aspergillus candidus. Colonies after 7 days incubation (A) Czapek Agar (B) MEA (C) A. candidus at 40x magnification.

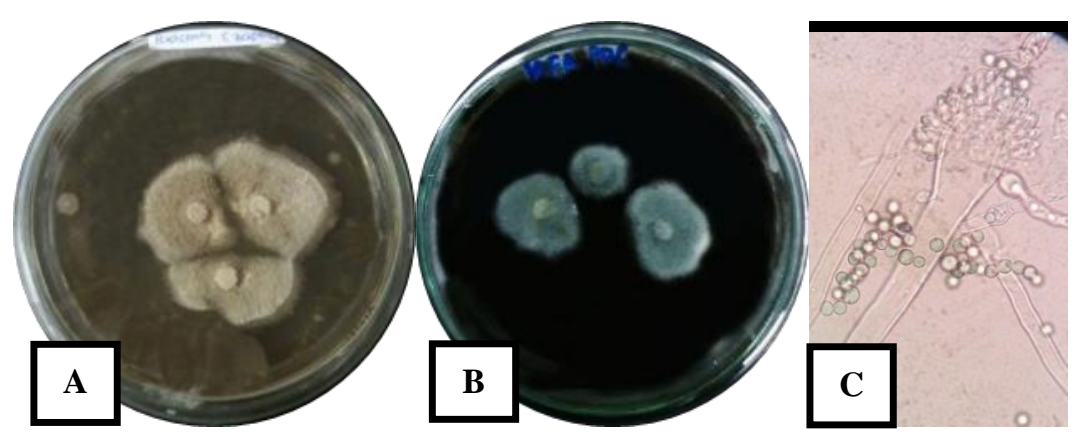

Fig. 6: Aspergillus clavatus. Colonies after 7 days incubation (A) Czapek Agar (B) MEA (C) A. clavatus at 40x magnification.
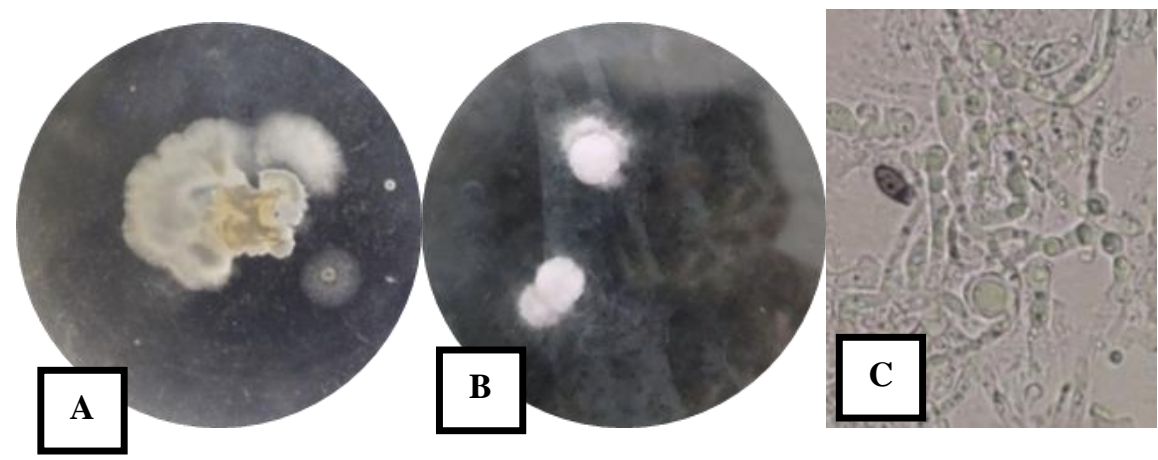

Fig. 7: Geotrichum sp. Colonies after 7 days incubation (A) Czapek Agar (B) MEA (C) Isolate SLKP at 40× magnification 

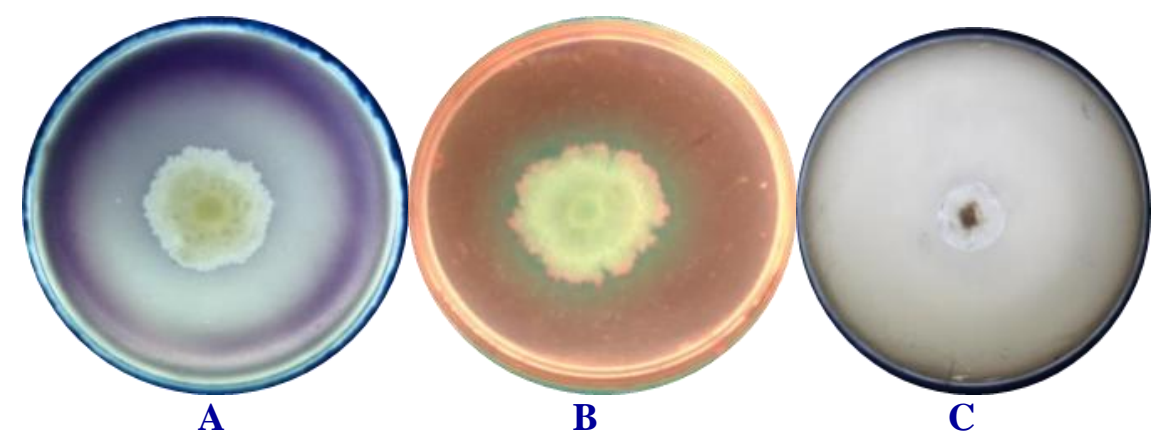

Fig. 8: In-vitro potential of amylolytic mold (Geotrichum sp.) on some selective medium (A) Amylolytic, (B)

Cellulolytic and (C) Fermentative.

Table 1. Value of in-vitro potential index of amylolytic mold isolates.

\begin{tabular}{lllll}
\hline Isolate & Hydrolysis & Halo diameter $(\mathbf{c m})$ & Colony diameter $(\mathbf{c m})$ & Index value \\
\hline SLKP & Amylolytic & $\mathbf{7}$ & $\mathbf{3 . 3}$ & $\mathbf{2 . 1 2}$ \\
& Cellulolytic & 10.1 & 7.3 & 1.38 \\
PYKP & Fermentative & 1.3 & 1 & 1.3 \\
& Amylolytic & $\mathbf{1 1 . 3}$ & $\mathbf{9}$ & $\mathbf{1 . 2 5}$ \\
& Cellulolytic & 5.9 & 4.7 & 1.25 \\
BTKP & Fermentative & - & 0.6 & - \\
& Amylolytic & $\mathbf{4}$ & $\mathbf{3 . 9}$ & $\mathbf{1 . 0 2}$ \\
& Cellulolytic & 8.9 & 6.2 & 1.43 \\
PPKP & Fermentative & 1.1 & 0.9 & 1.2 \\
& Amylolytic & $\mathbf{5 . 5}$ & $\mathbf{3 . 3}$ & $\mathbf{1 . 6}$ \\
& Cellulolytic & 4.8 & 3.3 & 1.45 \\
PSKP & Fermentative & 1.4 & 1 & 1.4 \\
& Amylolytic & $\mathbf{3 . 7}$ & $\mathbf{2 . 7}$ & $\mathbf{1 . 3 7}$ \\
& Cellulolytic & 4.2 & 3.2 & 1.31 \\
PJKP & Fermentative & 1.5 & 0.6 & 2.5 \\
& Amylolytic & $\mathbf{1 . 9}$ & $\mathbf{1 . 3}$ & $\mathbf{1 . 4 6}$ \\
& Cellulolytic & 2.7 & 2.5 & 1.08 \\
PDKP & Fermentative & 1 & 0.8 & 1.25 \\
& Amylolytic & $\mathbf{5 . 4}$ & $\mathbf{4 . 9}$ & $\mathbf{1 . 1 0}$ \\
& Cellulolytic & 3.9 & 2.8 & 1.39 \\
\hline Description: BTKP Isolate (Aspergillus oryzae), PSKP Isolate (Aspergillus terreus), PPKP Isolate (Aspergillus \\
fumigatus), PJKP Isolate (Aspergillus oryzae), PYKP Isolate (Aspergillus candidus), PDKP Isolate (Aspergillus \\
clavatus), SLKP Isolate (Getrichum sp.).
\end{tabular}

\section{Potency in-vitro of amylolytic microbial isolates}

The results of potency in-vitro examination of isolate can be seen in Fig. 8 .

Fig. 8 shows that in addition to amylolytic potential, the isolates of mold also have cellulolytic and fermentative potentials. This potential can be seen from the clear zone formation around the colony on each selective medium. The ability was measured into an Index values. Index values include amylolytic, cellulolytic, and fermentative index. The values are shown in Table 1.

Table 1 showed that all isolate of mold from several samples ragi tapai have amylolytic, cellulolytic and fermentative ability with different index. This can be seen from the index values of each isolate on 
some selective medium, i.e. APB, CMCA and GPA $+\mathrm{CaCO}_{3}$. Geotrichum sp. was the mold that has the highest amylolytic index which is 2.12. Geotrichum sp. can be used as the most potential mold, in the conversion of starch to sugar. According to OchoaSolano and Olmos-soto (2006). The isolates that able to produced clear zone with diameter twice colony diameter can be classified as potential enzyme producers. The high index of amylolytic potential rather than cellulolytic and fermentative indicates that Geotrichum sp. isolated from ragi tapai can be a potential isolate in saccharification.

From several West Sumatra local ragi tapai (Padang, Padang Panjang, Pesisir Selatan, Payakumbuh, Solok, Padang Pariaman, Batusangkar) 6 species of amylolytic mold were found. Those were Aspergillus oryzae, Aspergillus terreus, Aspergillus fumigatus, Aspergillus candidus, Aspergillus clavatus and Geotrichum sp. Highest in-vitro potential of amylolytic activity was found in Geotricum sp.

\section{References}

Adini, S., Kusdiyantini, E., Anto Budiharjo, 2015. Produksi bioetanol dari rumput laut dan limbah agar Gracilaria sp. dengan metode sakarifikasi yang berbeda. Bioma. 16(2), 65-75.

Alexopoulus, C. J., Mims, C. W., 1979. Introductory Mycology. $3^{\text {rd }}$ Edn. John Wiley and Sons, New York.

Burnett, H. L., Hunter, B.B., 1972. Illustrated Genera of Imperfect Fungi. $3^{\text {rd }}$ Edn. Burgess Publishing Company, Minneapolis.

Dwita, S., 2009. Penggunaan Kombinasi Suhu Dan Lama Inkubasi Dalam Peningkatan Produksi Amilase Beberapa Jamur Ragi Tapai Sumatera Barat. Skripsi jurusan Biologi Universitas Andalas, Padang.

Gandjar, I., 2003. Tape from Cassava and Cereals.
Department of Biology, Faculty of Mathematics and Natural Sciences, University of Indonesia, Jakarta.

Handayani, W., 2007. Penambahan Beberapa Jenis Rempah Terhadap Keberadaan Mikroflora Ragi Tapai. Skripsi Sarjana Biologi Universitas Andalas, Padang.

Jamilah, I. T., Meryandini, A., Rusmana, I., Suwanto, A., Mubarik, N.R., 2009. Activity proteolytic and amylolytic and enzymes from Bacillus spp. isolated from shrimp ponds. J. Microbiol. Indonesia. 3(2), 67-71.

Lima, M.A.P and A.P.P Natalense, 2012. Bioetahnol. Brazilian Bioethanol Science and Technology Laboratory (CTBE). Brazil.

Melliawati, R., Rohmatussolihat, Octavina, F., 2006. Seleksi mikroorganisme potensial untuk fermentasi pati sagu. Biodiversitas. 7(2), 101104.

Ochoa-Solano, J. L., Olmos-Soto, J., 2006. The functional property of Bacillus for shrimp feeds. Food Microbiol. 23(6), 519-525.

Oramahi, H.A., 2006. Identifikasi jamur amilolitk pada geplek di kabupaten gunung kidul. J. Perlind. Tanaman Indon. 12(1), 25-32.

Periadnadi, 2005. Hubungan antara Komposisi Ragi Tapai dari Beberapa Daerah di Sumatera Barat dengan Tapai yang Dihasilkannya. Makalah Regularly Scientific Seminar TPSDP Batch III Jurusan Biologi FMIPA Universitas Andalas Padang. 14 Desember 2005.

Samson, R. A., von Reenen- Hoekstra, E. S., 1988. Introduction to Food Born Fungi. Central Bureau Voor Schimmel Cultures. BAARN, The Netherland.

Wangge, E.S.A., Suprapta, D.N., Ngurah Ali, G., 2012. Isolasi dan identifikasi jamur penghasil mikotoksin pada biji kakao kering yang dihasilkan di flores. J. Agric. Sci. Biotechnol. 1(1), 39-47.

\section{How to cite this article:}

Inelvi Yulia, Periadnadi and Nurmiati. 2018. Selection and in-vitro potentials of amylolytic mold from several local ragi tapai in West Sumatra. Int. J. Curr. Res. Biosci. Plant Biol. 5(5), 49-55.

doi: https://doi.org/10.20546/ijcrbp.2018.505.008 